\title{
Development of a portable spectrofluorometer for measuring the quality of cheese
}

\author{
Romdhane KAROUI*, Éric DUFOUR \\ UR “Typicité des Produits Alimentaires”, ENITA de Clermont-Ferrand, Clermont Université, \\ BP 35, 63370 Lempdes, France
}

\begin{abstract}
The determination of some chemical parameters of Saint-Nectaire cheese samples (fat, dry matter (DM), $\mathrm{pH}$, total protein (TP) and soluble protein (SP)) was investigated using fluorescence spectroscopy. A total of 12 cheeses (with a ripening time of 1 month) produced using different manufacturing processes and ripened in different conditions - farmhouse Saint-Nectaire ripened at a farmhouse $(n=3)$, farmhouse Saint-Nectaire ripened at a dairy plant $(n=3)$, Saint-Nectaire "Laitier" ripened at a dairy plant $(n=3)$ and Savaron $(n=3)$ ripened at a dairy plant - were analyzed by laboratory and portable spectrofluorometers developed at the Foodstuffs Unit of ENITA Clermont-Ferrand. Partial least squares (PLS) regression with the leave-one-out cross-validation technique was used to perform calibration models. The best results for $\mathrm{DM}\left(\mathrm{R}^{2}=0.91\right.$; ratio of standard deviation to root mean square error of prediction $(\mathrm{RPD})=3.37), \mathrm{TP}\left(\mathrm{R}^{2}=0.86\right.$; $\mathrm{RPD}=$ $2.71)$, fat $\left(\mathrm{R}^{2}=0.83 ; \mathrm{RPD}=2.42\right)$ and $\mathrm{SP}\left(\mathrm{R}^{2}=0.65 ; \mathrm{RPD}=1.66\right)$ were obtained with the portable fluorometer, with the excitation wavelength set at $380 \mathrm{~nm}$. Regarding the prediction of $\mathrm{pH}$ value, the best results were also obtained with the portable fluorometer with excitation set at $280 \mathrm{~nm}$ $\left(\mathrm{R}^{2}=0.74 ; \mathrm{RPD}=1.98\right)$. It could be concluded that the portable spectrofluorometer could be used as a suitable technique for the prediction of DM, TP and fat. The SP and $\mathrm{pH}$ could also be estimated, but with much lower precision.
\end{abstract}

\section{Saint-Nectaire cheese / portable spectrofluorometer / laboratory spectrofluorometer /} calibration model / partial least squares method

摘要 - 利用便携式苂光分光光度计测定干酪质量。本文使用苂光分光光度计测定了 12 个 不同加工工艺和成熟条件下生产的 (成熟期为 1 个月) Saint-Nectaire 干酪的脂肪、干物质 含量 $(\mathrm{DM}) 、 \mathrm{pH}$ 值、总蛋白 (TP) 和可溶性蛋白 (SP)。其中 3 例 Saint-Nectaire 干酪是在 农家成熟, 3 例 Saint-Nectaire 干酪是在乳品厂成熟, 3 例 Laitier Saint-Nectaire 干酪是在乳品 厂成熟, 3 例 Savaron 干酪是在乳品厂成熟, 样品分别经实验室用苂光分光光度计和 ENITA Clermont-Ferrand 食品原料公司研制的便携式苂光分光光度计分析。采用留一法交互校验法 建立了偏最小二乘 (PLS) 回归的校正模型。使用便携式苂光分光光度计, 在 $380 \mathrm{~nm}$ 激发波 长处测定了 $\mathrm{DM}\left(\mathrm{R}^{2}=0.91\right.$, 标准差与预测误差均方根的比值 $\left.(\mathrm{RPD})=3.37\right), \mathrm{TP}\left(\mathrm{R}^{2}=0.86\right.$; $\mathrm{RPD}=2.71)$, 脂肪 $\left(\mathrm{R}^{2}=0.83 ; \mathrm{RPD}=2.4\right)$ 和 $\mathrm{SP}\left(\mathrm{R}^{2}=0.65 ; \mathrm{RPD}=1.66\right)$ 的最佳实验结果。对 于 $\mathrm{pH}$ 值的预测, 在 $280 \mathrm{~nm}$ 的激发波长下也获得了最佳结果 $\left(\mathrm{R}^{2}=0.74 ; \mathrm{RPD}=1.98\right)$ 。由此 可见便携式苂光分光光度计可以有效地预测 $\mathrm{DM}$, TP 和脂肪含量。也可以预测 SP 和 $\mathrm{pH}$ 值, 但精确度较低。

Saint-Nectaire 干酪 / 便携式苂光光度计 / 实验室用苂光光度计 / 校正模型 / 偏最小二乘法

*Corresponding author (通讯作者): karouiromdhane@yahoo.fr 


\begin{abstract}
Résumé - Développement d'un spectrofluorimètre portatif pour mesurer la qualité des fromages. La mesure de quelques paramètres chimiques de fromages de Saint-Nectaire (matière grasse, extrait sec, $\mathrm{pH}$, protéines totales et protéines solubles) a été déterminée par spectroscopie de fluorescence. Au total, 12 fromages de Saint-Nectaire (ayant un temps d'affinage de 1 mois) ont été fabriqués en utilisant différents procédés de fabrication et conditions d'affinage - Saint-Nectaire fermier affiné dans une ferme $(n=3)$, Saint-Nectaire fermier affiné dans une laiterie $(n=3)$, SaintNectaire "Laitier" affiné dans une laiterie $(n=3)$ et Savaron $(n=3)$ affiné dans une laiterie ont été analysés par un spectrofluorimètre du laboratoire et le spectrofluorimètre portatif développé au sein de l'Unité de Recherche «Typicité des Produits Alimentaires » (UR TPA) de l'ENITA de Clermont-Ferrand. La méthode des moindres carrés partiels avec validation croisée a été utilisée pour développer des modèles de calibrage, et ce pour tous les paramètres chimiques. Les meilleurs résultats pour l'extrait $\sec \left(R^{2}=0,91 ; R P D=3,37\right)$, les protéines totales $\left(R^{2}=0,86 ; R P D=2,71\right)$, la matière grasse $\left(R^{2}=0,83 ; R P D=2,42\right)$ et les protéines solubles $\left(R^{2}=0,65 ; R P D=1,66\right)$ ont été obtenus avec le spectrofluorimètre portatif, après excitation à $380 \mathrm{~nm}$. Concernant la détermination de la valeur du $\mathrm{pH}$, les meilleurs résultats ont été obtenus également avec le spectrofluorimètre portatif après excitation à $280 \mathrm{~nm}\left(\mathrm{R}^{2}=0,74 ; \mathrm{RPD}=1,98\right)$. Le spectrofluorimètre portatif peut être considéré comme une technique appropriée pour la détermination de l'extrait sec et des teneurs en protéines totales et en matière grasse. Les teneurs en protéines solubles et le $\mathrm{pH}$ peuvent être également prédits, mais avec une précision beaucoup plus faible.
\end{abstract}

Saint-Nectaire / spectrofluorimètre portatif / spectrofluorimètre de laboratoire / modèle de calibration / méthode des moindres carrés partiels

\section{INTRODUCTION}

Rapid screening techniques for determining quality characteristics of cheeses are of great interest for both industry and consumers. The dairy industry, like the food processing industry in general, has come under increasing pressure to deliver products of high and constant quality into the market place. The chemical determination of cheeses is a very important task, which is classically undertaken by different physico-chemical methods to determine $\mathrm{pH}$ value, fat and calcium contents, nitrogen fractions, etc. This approach suffers from a number of disadvantages, namely, the ever-increasing range of analytes, which must be included in any test procedure and the limited knowledge of the range of each constituent in normal lots of the substance. In addition, the abovementioned methods require sophisticated analytical equipment and skilled operators; they are also time-consuming and need both the purchase and disposal of chemical reagents. For all these reasons, there is a continuing demand for new, rapid and relatively cheaper methods for direct quality measurements in food and food ingredients.

Nowadays, there is a need for the cheese processing industry to have tools available for real-time control of production lines to check whether in-process material, during a given processing step, meets the necessary compositional or functional specifications to reach a predetermined quality standard in the final product. In this context, fluorescence spectroscopy could be considered as fast, relatively low-cost and provides a great deal of information with only one test [5]. It is sensitive, non-destructive, rapid, environmentally friendly and noninvasive, making it suitable for at-line or on-line process control and appropriate for process control.

Several papers have demonstrated the ability of fluorescence spectroscopy as a rapid technique for the determination of the quality of different dairy products. Indeed, Christensen et al. [3] used this technique to predict riboflavin content in 42 yogurt samples, obtaining successful results and underlining the potential of fluorescence spectroscopy to be utilized as a rapid method for the determination of riboflavin 
content in dairy products. This technique has been also utilized for the determination of: (1) lactulose and furosine in milks [20] and (2) some chemical parameters in different soft cheese varieties in both the external and central zones [18]. Karoui et al. [10] and Purna et al. [23] have also used front-face fluorescence spectroscopy as a non-destructive technique to determine the cheese melting point of semi-hard cheeses produced during summer and autumn periods and commercial cheese samples, respectively. The authors pointed out the ability of fluorescence spectroscopy to predict cheese melting point as well as some chemical parameters.

However, all these studies were performed on cheese samples produced at the industrial level and by using standard laboratory-based spectrofluorometers $[4,7-18,21,27]$. No research using this technique has been performed on farmhouse cheeses such as Saint-Nectaire.

The aim of the present study is to examine the feasibility of laboratory and portable spectrofluorometers, comprising a light-emitting diode (LED) for excitation, a spectrometer, a fiber optic and an integrated PC with a touch-screen for recording and evaluating data sets, for the determination of some chemical parameters $(\mathrm{pH}$, fat, dry matter (DM), total protein (TP) and soluble protein (SP)) of 12 French semi-hard cheeses belonging to four brands. For a given chemical parameter, an optimal calibration model developed using laboratory and portable spectrofluorometers and partial least squares (PLS) regression was selected.

\section{MATERIALS AND METHODS}

\subsection{Cheese samples}

Twelve different Saint-Nectaire cheeses belonging to four brands, obtained directly from different farms and dairies, were available in the laboratory after less than 1 h. Farmhouse Saint-Nectaire ( $n=$ 3) ripened at the farmhouse, Farmhouse Saint-Nectaire $(n=3)$ ripened at the dairy plant, Saint-Nectaire "Laitier" $(n=3)$ ripened at the dairy plant and Savaron $(n=$ 3 ) ripened at the dairy plant were produced using different manufacturing processes and ripening conditions with a ripening time of 1 month. Farmhouse cheeses were produced with raw milk, while the other investigated cheeses were made with pasteurized milk. Each cheese was cut into two symmetric parts according to its median line. One section was used for chemical analyses, the other for fluorescence spectroscopic measurements. The acquisitions of fluorescence spectra by the two apparatus were determined on different fresh cheese slices.

\subsection{Physico-chemical analyses}

The determination of $\mathrm{pH}, \mathrm{DM}$, fat, TP and SP contents of the analyzed cheeses was as described by Bouton et al. [2]. All cheese samples were kept at $-20{ }^{\circ} \mathrm{C}$ for approximately 7 months until analysis. All the analyses were carried out in triplicate.

\subsection{Laboratory spectrofluorometer}

For each fresh cheese, three slices $(2 \mathrm{~cm}$ length, $1 \mathrm{~cm}$ width and $0.2 \mathrm{~cm}$ thickness) were obtained using a controlled thickness wire cutter. Fluorescence spectra were recorded using a FluoroMax-2 spectrofluorometer (Spex-Jobin Yvon, Longjumeau, France). The incidence angle of the excitation radiation was set at $56^{\circ}$ to ensure that reflected light, scattered radiation and depolarization phenomena were minimized. Cheese samples were mounted between two quartz slides and spectra were recorded at $20{ }^{\circ} \mathrm{C}$. The emission spectra (305-400 nm), (330-500 nm) and (400$640 \mathrm{~nm}$ ) were recorded with the excitation wavelengths set at $280 \mathrm{~nm}, 320 \mathrm{~nm}$ 


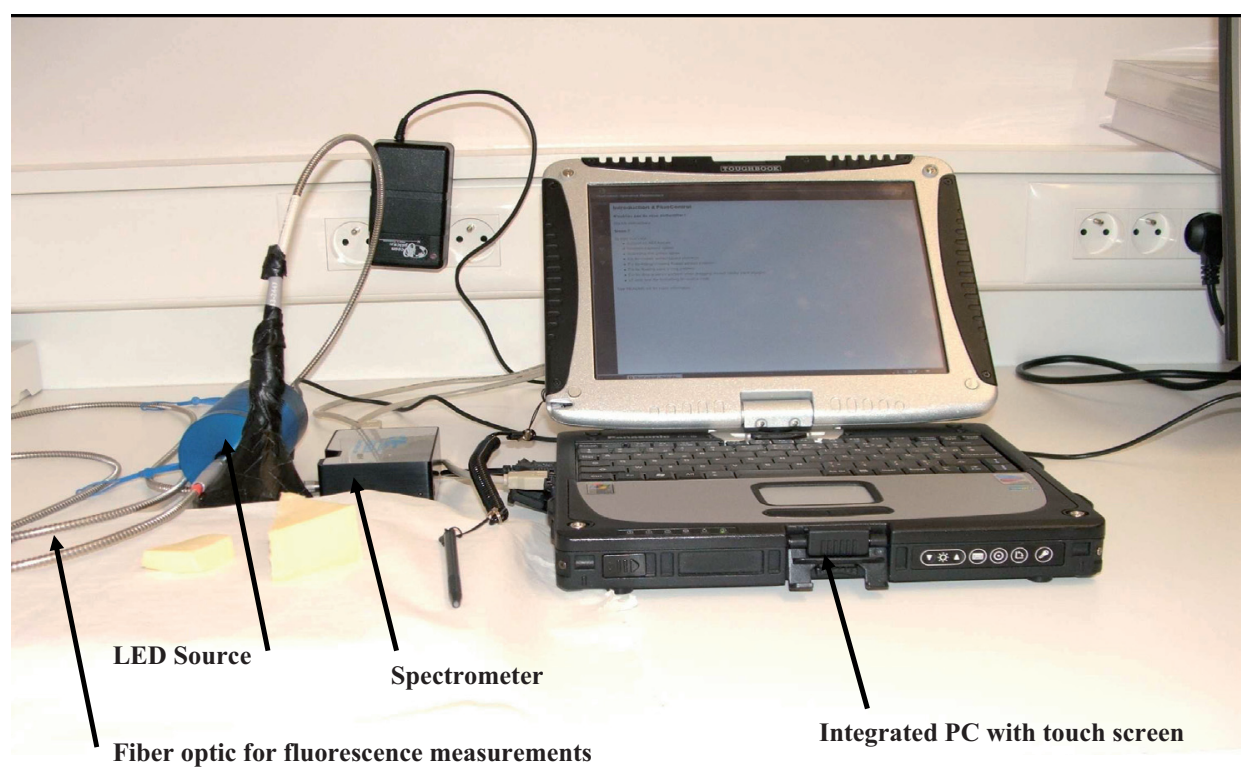

Figure 1. Integrated portable spectrofluorometer.

and $380 \mathrm{~nm}$, respectively. All the spectra were corrected for instrumental distortions in excitation using a rhodamine cell in the reference channel. Analyses were done in triplicate for each cheese sample.

\subsection{Portable spectrofluorometer}

For each fresh cheese, three slices $(2 \mathrm{~cm}$ length, $1 \mathrm{~cm}$ width and $0.2 \mathrm{~cm}$ thickness) were obtained using a controlled thickness wire cutter. The portable apparatus consisted of a commercially available compact device for fluorescence analysis. As shown in Figure 1 the portable spectrofluorometer is composed of a light-emitting diode (LED) source, a spectrometer, a fiber optic and an integrated PC with a touch-screen for recording and evaluating data sets. All the instruments were purchased from IDIL Fibres Optiques (Lannion, France).

The emission spectra $(307-460 \mathrm{~nm})$, (346-600 nm) and (410-705 nm) were recorded with the excitation wavelengths set at $280 \mathrm{~nm}, 320 \mathrm{~nm}$ and $380 \mathrm{~nm}$, respectively. All spectra were corrected by subtracting the dark for each measurement. The dark was acquired with no light source.

\subsection{Principal component analysis (PCA)}

In order to determine the variability in the physico-chemical parameters and the effect of the manufacturing process and ripening conditions for the investigated cheeses, principal component analysis (PCA) was used. PCA transforms the original variables (chemical parameters) into new axes called principal components (PCs), which are orthogonal, so that the data sets presented on these axes are uncorrelated with each other. This statistical multivariate treatment was earlier used to differentiate between different cheese samples according to their manufacturing processes, ripening stages and geographical origins $[4,7,10]$, reducing the dimension 
to two or three PCs, keeping most of the original information found in the data set. The PCA was performed on the chemical parameters by using StatBoxPro ${ }^{\circledR}$ software (version 5.0, Paris, France).

\subsection{Partial least squares (PLS) regression}

The objective of this task was to perform a statistical model between the processed spectra and cheese properties (chemical parameters). Because the number of the wavelengths in the different fluorescence spectra was much larger than the number of cheese samples in the data set, it was necessary to use chemometric tools to extract information from the data set. Several statistical modeling techniques can be adopted for proper calibration performance, such as linear and nonlinear multiple regression analysis, principal component regression (PCR) and PLS regression. In the present study, PLS regression was used in order to predict some chemical parameters $(\mathrm{pH}$, fat, DM, $\mathrm{TP}$ and SP) of the investigated cheese samples from the fluorescence spectral data sets. For each excitation wavelength and for each chemical parameter, two different models (using laboratory or portable spectrofluorometers) were developed utilizing fluorescence spectra. As the number of observations was small, the regression models were validated by a leave-oneout cross-validation. This cross-validation enables the dimensions of the predictive model to be chosen. The optimum number of latent variables (LV) was chosen by the software automatically. PLS regression was performed using Unscrambler ${ }^{\circledR}$ software (version 7.8, Camo Process AS, Norway).

In order to compare the different established models for a given parameter, the values of the root mean square error of prediction (RMSEP) of the calibration set were considered. The performance of the models was quantified by determining the $\mathrm{R}^{2}$ for predicted versus measured compositions in cross-validation and the ratio of standard deviation (SD) of the data set to the RMSEP. In fact, $\mathrm{R}^{2}$ indicates the percentage of the variance in the $Y$ variable that is accounted for by the $X$ variable. Values of $\mathrm{R}^{2}$ comprised between 0.50 and 0.65 indicate that more than $50 \%$ of the variance in $Y$ is accounted for by variance $X$; thus, differentiation between only high and low values can be observed. A value for $\mathrm{R}^{2}$ from $0.66-0.81$ and $0.82-$ 0.90 indicates approximate and good prediction, respectively. Calibration models with a value for $\mathrm{R}^{2}$ above 0.91 are considered to be excellent [26]. The ratio of the SD to the RMSEP, called the ratio of prediction to deviation (RPD), is the factor by which the prediction accuracy increased compared with the use of the mean composition for all samples. This ratio is desired to be larger than 5, but at least 3, for a good calibration [26]. A RPD ratio less than 2 indicates poor predictions and the model cannot be used for further prediction. Practical utility of the calibrations can also be assessed using the range error ratio (RER) [22]. This ratio is calculated by dividing the range of a given constituent by the prediction error for that constituent and, while susceptible to the presence of extreme values at both ends of the range, it is a useful indicator of the practical utility of a predictive model.

\section{RESULTS AND DISCUSSION}

\subsection{Physico-chemical measurements}

The results for fat, $\mathrm{DM}, \mathrm{pH}, \mathrm{TP}$ and $\mathrm{SP}$ of the analyzed cheeses are reported in Table I. The obtained results were in agreement with previous findings $[1,25]$.

In order to determine the effect of the manufacturing process and ripening conditions on the chemical parameters of 
Table I. Physico-chemical composition of Saint-Nectaire cheese samples used for the PLS-crossvalidation model $^{\mathrm{a}}$.

\begin{tabular}{|c|c|c|c|c|c|c|}
\hline \multirow[b]{2}{*}{ Cheese samples } & & \multicolumn{5}{|c|}{ Physico-chemical composition } \\
\hline & & $\begin{array}{l}\text { DM } \\
\left(\mathrm{g} \cdot 100 \mathrm{~g}^{-1}\right)\end{array}$ & $\begin{array}{l}\text { Fat } \\
\left(\mathrm{g} \cdot 100 \mathrm{~g}^{-1}\right)\end{array}$ & $\mathrm{pH}$ & $\begin{array}{l}\text { TP } \\
\left(\mathrm{g} \cdot 100 \mathrm{~g}^{-1}\right)\end{array}$ & $\begin{array}{l}\text { SP } \\
\left(\mathrm{g} \cdot 100 \mathrm{~g}^{-1}\right)\end{array}$ \\
\hline $\begin{array}{l}\text { Farmhouse Saint-Nectaire } \\
\text { produced with raw milk } \\
\text { and ripened at the farmhouse } \\
(n=3)\end{array}$ & $\begin{array}{l}\text { Mean } \\
\text { SD }\end{array}$ & $\begin{array}{r}55.138 \\
1.132\end{array}$ & $\begin{array}{r}30.389 \\
0.953\end{array}$ & $\begin{array}{l}5.716 \\
0.205\end{array}$ & $\begin{array}{r}22.226 \\
0.445\end{array}$ & $\begin{array}{l}1.934 \\
1.128\end{array}$ \\
\hline $\begin{array}{l}\text { Farmhouse Saint-Nectaire } \\
\text { produced with raw milk } \\
\text { and ripened at the dairy } \\
\text { plant }(n=3)\end{array}$ & $\begin{array}{l}\text { Mean } \\
\text { SD }\end{array}$ & $\begin{array}{r}55.874 \\
3.839\end{array}$ & $\begin{array}{r}32.444 \\
2.715\end{array}$ & $\begin{array}{l}5.659 \\
0.109\end{array}$ & $\begin{array}{r}21.648 \\
0.505\end{array}$ & $\begin{array}{l}2.995 \\
0.412\end{array}$ \\
\hline $\begin{array}{l}\text { Saint-Nectaire "Laitier" } \\
\text { produced with pasteurized } \\
\text { milk and ripened at the dairy } \\
\text { plant }(n=3)\end{array}$ & $\begin{array}{l}\text { Mean } \\
\text { SD }\end{array}$ & $\begin{array}{r}56.868 \\
0.808\end{array}$ & $\begin{array}{r}30.056 \\
0.527\end{array}$ & $\begin{array}{l}5.811 \\
0.239\end{array}$ & $\begin{array}{r}23.750 \\
0.366\end{array}$ & $\begin{array}{l}2.814 \\
1.430\end{array}$ \\
\hline $\begin{array}{l}\text { Savaron produced with } \\
\text { pasteurized milk and ripened } \\
\text { at the dairy plant }(n=3)\end{array}$ & $\begin{array}{l}\text { Mean } \\
\text { SD }\end{array}$ & $\begin{array}{r}56.658 \\
4.078\end{array}$ & $\begin{array}{r}27.389 \\
2.346\end{array}$ & $\begin{array}{l}5.873 \\
0.237\end{array}$ & $\begin{array}{r}25.110 \\
0.700\end{array}$ & $\begin{array}{l}4.019 \\
0.906\end{array}$ \\
\hline $\begin{array}{l}\text { Samples used for the } \\
\text { calibration }(n=12)\end{array}$ & $\begin{array}{l}\text { Minimum } \\
\text { Maximum } \\
\text { Mean } \\
\text { SD }\end{array}$ & $\begin{array}{r}53.270 \\
60.940 \\
56.130 \\
2.840\end{array}$ & $\begin{array}{r}25.500 \\
36.000 \\
30.070 \\
2.560\end{array}$ & $\begin{array}{l}5.480 \\
6.070 \\
5.760 \\
0.210\end{array}$ & $\begin{array}{r}20.850 \\
25.980 \\
23.170 \\
1.450\end{array}$ & $\begin{array}{l}1.230 \\
4.800 \\
2.960 \\
1.170\end{array}$ \\
\hline
\end{tabular}

a Abbreviations: DM, dry matter; TP, total protein; SP, soluble protein; SD, standard deviation.

the investigated cheeses, PCA was applied to the normalized data sets. The normalization consists of dividing each column by the corresponding standard deviation. The obtained results (data not shown) showed a good separation between farmhouse cheeses (ripened at the farmhouse or the dairy plant), which presented mostly negative score values according to PC1, and Saint-Nectaire Laitier and Savaron (ripened at the dairy plant), which exhibited mostly positive score values according to the PC1.

\subsection{Fluorescence spectra of different cheese samples}

Typical fluorescence spectra recorded with laboratory and portable spectroflu- orometer instruments are shown in Figures 2-4.

Fluorescence spectra obtained with excitation set at $280 \mathrm{~nm}$ using a laboratory spectrofluorometer exhibited a maximum located at about $345 \mathrm{~nm}$ (Fig. 2a) varying slightly between cheese samples, while spectra recorded using a portable spectrofluorometer exhibited a maximum located around $345 \mathrm{~nm}$ and a slight one observed at $440 \mathrm{~nm}$ (Fig. 2b). This latter peak was attributed to fluorescence of the Maillard-reaction products, which present a maximum emission at $440 \mathrm{~nm}$ [20]. As shown in Figure $2 b$, there was a good discrimination between farmhouse cheeses and the others, which was not observed for cheese samples obtained by using the laboratory spectrofluorometer. The obtained results partially confirmed the findings of 
Karoui et al. $[9,13]$, reporting that a maximum located around $345 \mathrm{~nm}$ was observed for different cheese varieties and was attributed to tryptophan residues. The difference observed between the shapes of the spectra recorded on the investigated cheese samples could be due to the different molecular environments of tryptophan residues. One of the main conclusions of this study was that the portable spectrofluorometer could be considered as more sensitive than the laboratory spectrofluorometer. This could be due to the high number of measurement points collected with the portable spectrofluorometer (increment $\sim 0.3 \mathrm{~nm}$ ) compared with the laboratory spectrofluorometer (increment $1 \mathrm{~nm}$ ).

Regarding the emission spectra acquired with excitation wavelength set at $320 \mathrm{~nm}$, a maximum located around $410 \mathrm{~nm}$ was observed for cheese samples scanned by the laboratory spectrofluorometer (Fig. 3a). Considering spectra collected using the portable spectrofluorometer, maxima located around 405, 410, 422, 442, 488 and $510 \mathrm{~nm}$ were observed for all the cheese samples (Fig. 3b). The band located around $410 \mathrm{~nm}$ has, previously, been attributed to vitamin $\mathrm{A}$, as pointed out by several findings $[4,8]$. The difference observed between the spectra scanned on cheese samples could be related to the modification in the physical state of triglycerides in the fat globule during the ripening stage. Indeed, Dufour et al. [4] reported that the structure of triglyceride acyl chains in fat globules is modified during the ripening stage of semi-hard cheese. Again, a good differentiation between farmhouse cheeses and the other cheese samples was found with the portable spectrofluorometer.

Finally, the emission spectra scanned with excitation set at $380 \mathrm{~nm}$ using the laboratory and the portable spectrofluorometer(s) showed three spectral regions (Figs. 4a and 4b): the broad peak around
$523 \mathrm{~nm}$ (observed with the two instruments) is due to riboflavin compounds, as suggested previously by several authors $[21,24]$. The second region located between 410 and $480 \mathrm{~nm}$ shows fluorescence from stable oxidation products formed by aldehydes and amino acids [19]; lumichrome, a photo breakdown product from riboflavin, as well as $\beta$-carotene, exhibits fluorescence in the 410-480 nm [6], and could influence the shape of the fluorescence spectra. The last region observed, essentially, on cheese samples recorded with the laboratory spectrofluorometer is from 600 to $640 \mathrm{~nm}$, characteristic of porphyrin and chlorin compounds as has been reported by Wold et al. [27]. As we can notice, a good differentiation between farmhouse cheeses ripened at the farmhouse and dairy plant and the other cheese samples ripened at the dairy plant was observed with the portable spectrofluorometer.

The emission spectra of the investigated cheese samples are due to several fluorescent compounds occurring in the various cheese samples in different concentrations and different environments, leading to different spectral features of cheeses. In addition, as the number of point measurements (wavelengths) is higher than the number of cheese samples, it is essential to use multivariate statistical analysis to predict chemical parameters.

\subsection{Partial least squares regression}

Table I indicates the minimum, maximum, mean and standard deviation (SD) values of the investigated chemical parameters performed on cheese samples.

The best cross-validation results for the three different excitation wavelengths are presented in Table II. For all the investigated parameters, the optimum number of latent variables ( $\mathrm{LV}$ ) varies between 1 and 15. 


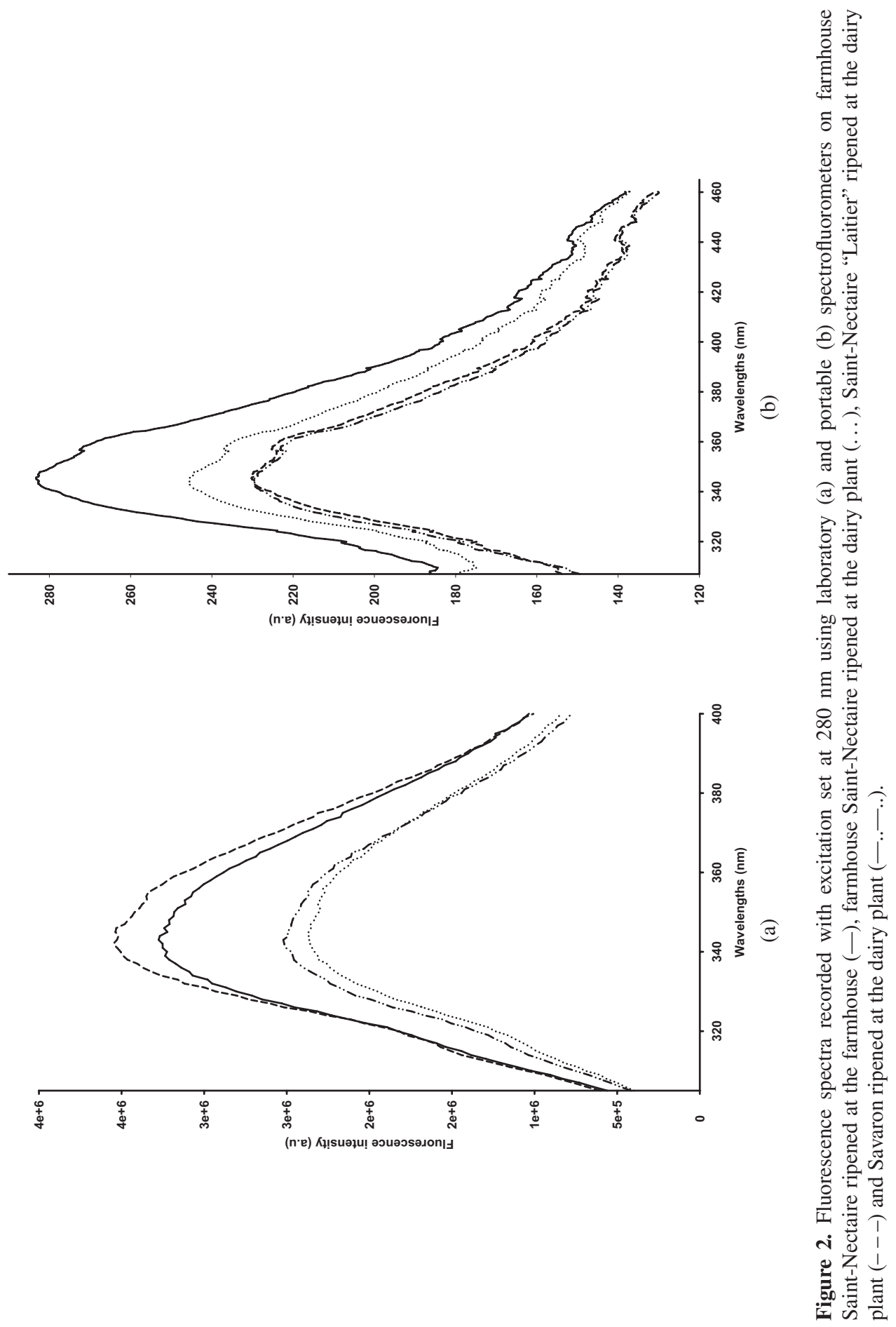




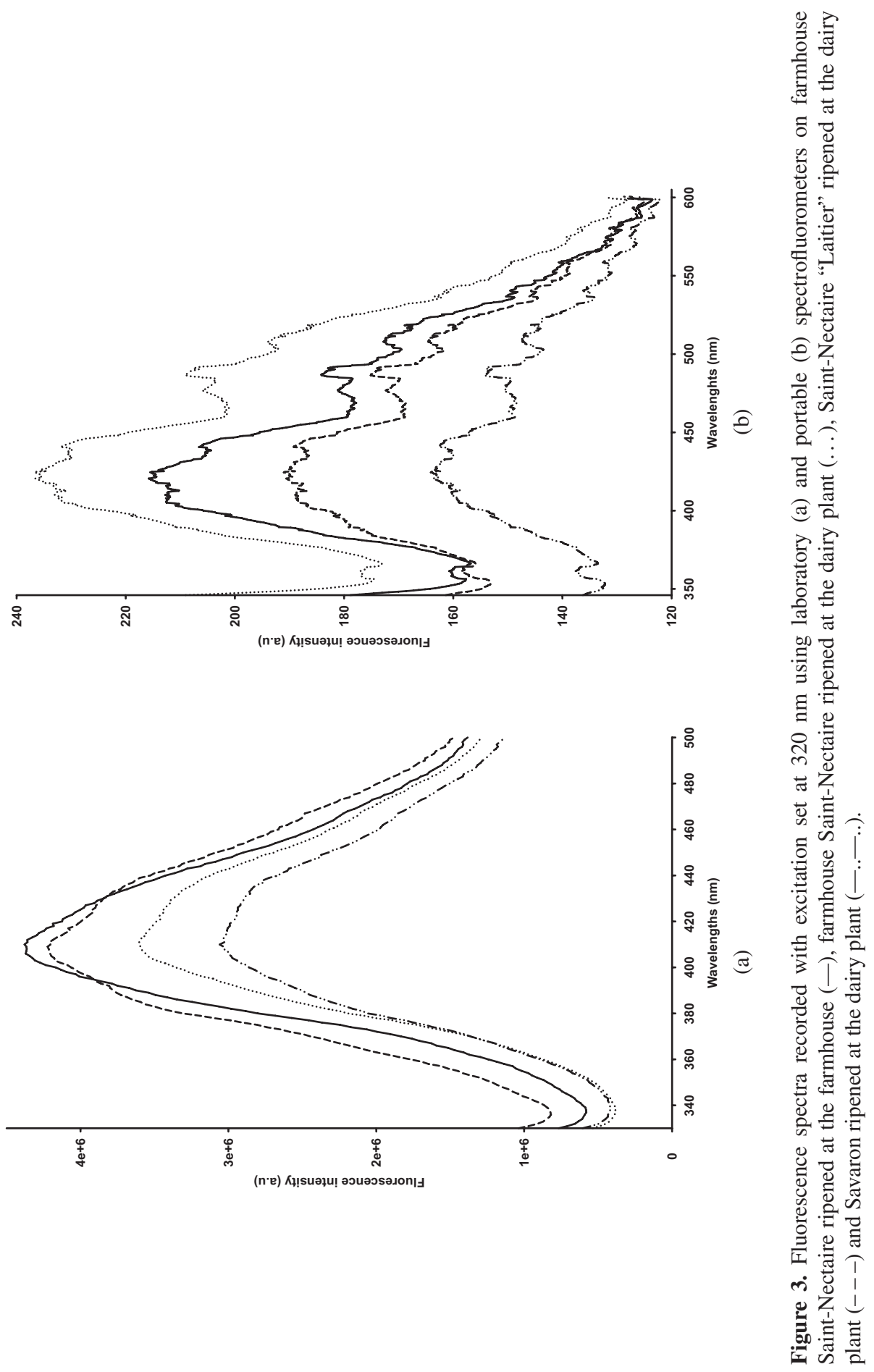




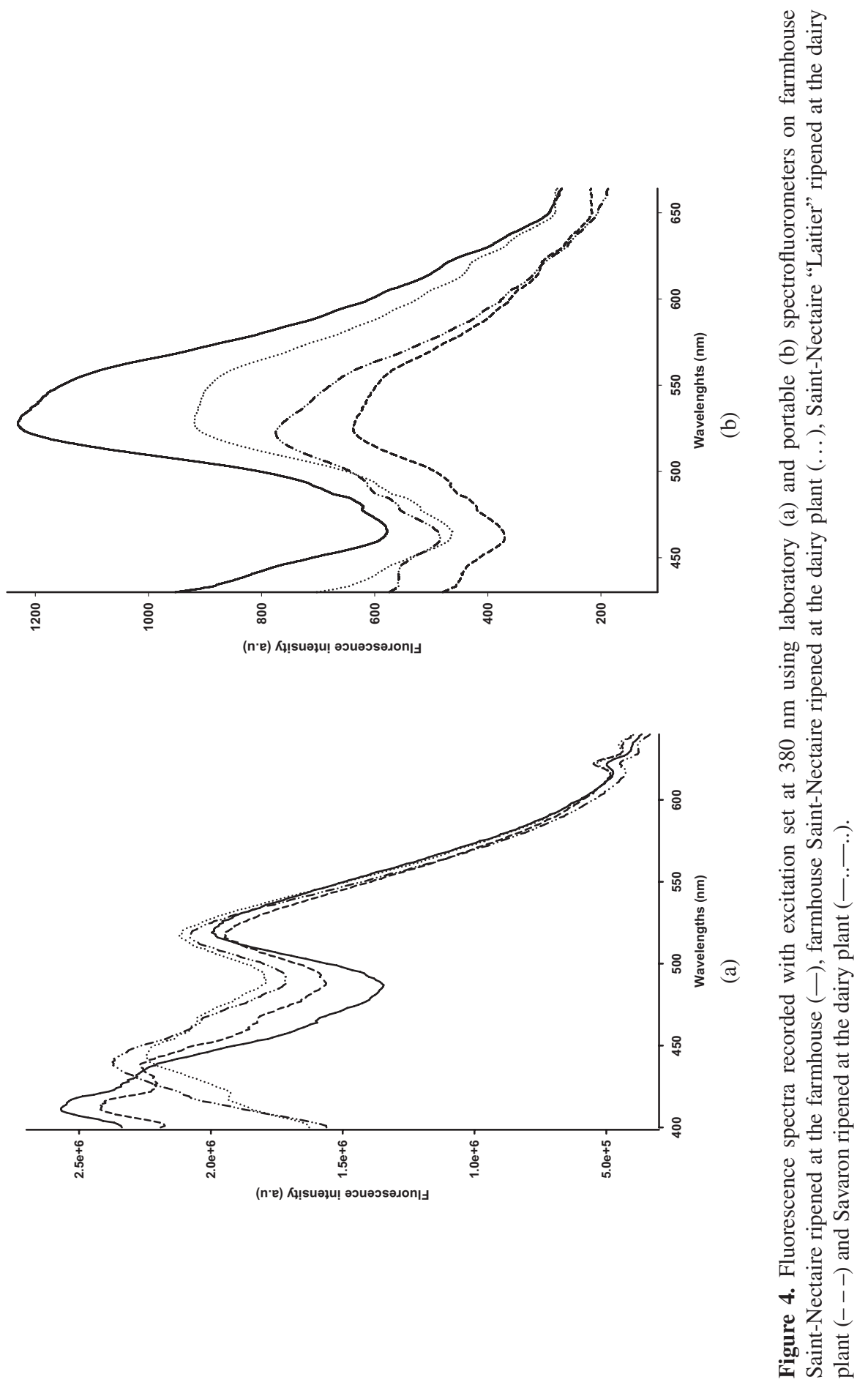


Table II. Validation results of the different excitation wavelengths: 280, 320 and $380 \mathrm{~nm}$ models developed with the PLS-cross-validation regression coefficient using the laboratory and portable spectrofluorometers ${ }^{\mathrm{a}}$.

\begin{tabular}{|c|c|c|c|c|c|c|c|}
\hline $\begin{array}{l}\text { Compositional } \\
\text { parameter }\end{array}$ & $\begin{array}{l}\text { Excitation wavelength } \\
(\mathrm{nm})\end{array}$ & $\overline{\mathrm{LV}}$ & $\overline{\mathrm{R}^{2}}$ & Slope & RMSEP & RPD & RER \\
\hline \multirow[t]{6}{*}{$\mathrm{pH}$} & 280: Laboratory & 4 & 0.25 & 0.35 & 0.19 & 1.14 & 3.15 \\
\hline & Portable & 15 & 0.74 & 0.81 & 0.11 & 1.98 & 5.44 \\
\hline & 320: Laboratory & 7 & 0.38 & 0.47 & 0.17 & 1.27 & 3.49 \\
\hline & Portable & 8 & 0.71 & 0.81 & 0.12 & 1.83 & 5.06 \\
\hline & 380: Laboratory & 1 & 0.01 & 0.03 & 0.22 & 0.98 & 2.69 \\
\hline & Portable & 13 & 0.51 & 0.67 & 0.15 & 1.39 & 3.83 \\
\hline \multirow[t]{6}{*}{ Fat $\left(\mathrm{g} \cdot 100 \mathrm{~g}^{-1}\right)$} & 280: Laboratory & 5 & 0.62 & 0.70 & 1.59 & 1.61 & 6.62 \\
\hline & Portable & 7 & 0.80 & 0.82 & 1.12 & 2.29 & 9.40 \\
\hline & 320: Laboratory & 5 & 0.80 & 0.85 & 1.14 & 2.24 & 9.21 \\
\hline & Portable & 4 & 0.75 & 0.78 & 1.27 & 2.02 & 8.29 \\
\hline & 380: Laboratory & 9 & 0.76 & 0.79 & 1.23 & 2.07 & 8.50 \\
\hline & Portable & 11 & 0.83 & 0.88 & 1.06 & 2.42 & 9.93 \\
\hline \multirow[t]{6}{*}{$\mathrm{DM}\left(\mathrm{g} \cdot 100 \mathrm{~g}^{-1}\right)$} & 280: Laboratory & 3 & 0.29 & 0.36 & 2.40 & 1.19 & 3.20 \\
\hline & Portable & 8 & 0.59 & 0.66 & 1.81 & 1.57 & 4.23 \\
\hline & 320: Laboratory & 8 & 0.75 & 0.78 & 1.41 & 2.02 & 5.44 \\
\hline & Portable & 11 & 0.71 & 0.83 & 1.57 & 1.81 & 4.88 \\
\hline & 380: Laboratory & 13 & 0.71 & 0.84 & 1.57 & 1.81 & 4.89 \\
\hline & Portable & 14 & 0.91 & 0.92 & 0.85 & 3.37 & 9.08 \\
\hline \multirow[t]{6}{*}{$\mathrm{TP}\left(\mathrm{g} \cdot 100 \mathrm{~g}^{-1}\right)$} & 280: Laboratory & 5 & 0.69 & 0.76 & 0.80 & 1.81 & 6.42 \\
\hline & Portable & 12 & 0.77 & 0.77 & 0.69 & 2.11 & 7.45 \\
\hline & 320: Laboratory & 7 & 0.68 & 0.74 & 0.81 & 1.78 & 6.30 \\
\hline & Portable & 11 & 0.67 & 0.77 & 0.84 & 1.73 & 6.10 \\
\hline & 380: Laboratory & 10 & 0.71 & 0.82 & 0.80 & 1.82 & 6.42 \\
\hline & Portable & 13 & 0.86 & 0.88 & 0.53 & 2.71 & 9.59 \\
\hline \multirow[t]{6}{*}{$\mathrm{SP}\left(\mathrm{g} \cdot 100 \mathrm{~g}^{-1}\right)$} & 280: Laboratory & 5 & 0.52 & 0.60 & 0.80 & 1.45 & 4.45 \\
\hline & Portable & 10 & 0.52 & 0.68 & 0.83 & 1.40 & 4.29 \\
\hline & 320: Laboratory & 5 & 0.27 & 0.38 & 1.01 & 1.15 & 3.54 \\
\hline & Portable & 8 & 0.65 & 0.76 & 0.70 & 1.67 & 5.13 \\
\hline & 380: Laboratory & 1 & 0.19 & 0.21 & 1.04 & 1.12 & 3.44 \\
\hline & Portable & 11 & 0.65 & 0.77 & 0.70 & 1.66 & 5.09 \\
\hline
\end{tabular}

a Abbreviations: DM, dry matter; TP, total protein; SP, soluble protein; LV, latent variables; $\mathrm{R}^{2}$, determination coefficient; RMSEP, root mean square error of prediction; RPD, ratio of prediction deviation (standard deviation/RMSEP); RER, range error ratio ([maximum - minimum]/RMSEP).

\subsubsection{Prediction of chemical parameters with the laboratory spectrofluorometer}

The best results for $\mathrm{pH}$, fat and $\mathrm{DM}$ were obtained with the excitation wavelength set at $320 \mathrm{~nm}$. Quite similar results were obtained with the three excitation wavelengths for TP, while the excitation wavelength set at $280 \mathrm{~nm}$ gave the best results for the prediction of SP. From the obtained results, it was concluded that measurements of fat, DM and TP could be considered as approximate by using the excitation wavelength set at $320 \mathrm{~nm}$ or $380 \mathrm{~nm}$. Measurements of SP could be used only for differentiating between low 


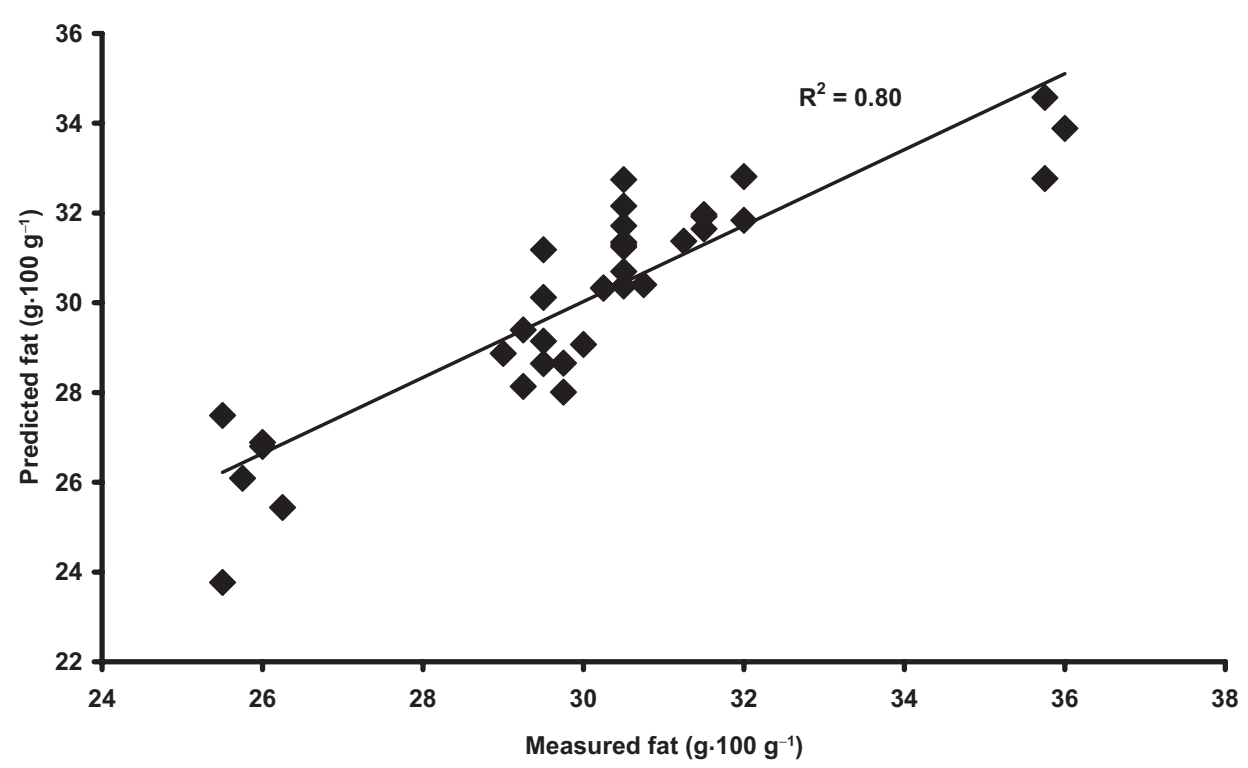

Figure 5. Partial least squares (PLS) prediction models: actual versus predicted value plots for cross-validation prediction of a training set of emission spectra scanned with excitation set at $320 \mathrm{~nm}$ using a laboratory spectrofluorometer for fat.

and high values by using only the excitation wavelength set at $280 \mathrm{~nm}$, since the other two excitation wavelengths $(320 \mathrm{~nm}$ and $380 \mathrm{~nm}$ ) gave unsuccessful results. Also, unsuccessful prediction of the $\mathrm{pH}$ value was observed, whatever the considered excitation wavelength. Using the excitation wavelength set at $320 \mathrm{~nm}$, the best results for fat and DM were obtained after applying range normalization to the fluorescence spectra $\left(\mathrm{R}^{2}=0.80 ; \mathrm{RPD}=2.24\right.$; $\mathrm{RER}=9.21$; Fig. 5$)$ and $\left(\mathrm{R}^{2}=0.75\right.$; $\mathrm{RPD}=$ 2.02; RER $=5.44)$, respectively (Tab. II). For the prediction of TP, the best result was obtained with the excitation wavelength set at $380 \mathrm{~nm}$ (Tab. II). The obtained results confirmed previous findings reporting that the best results for the prediction of fat and DM of 15 soft cheeses, produced by using different mesophilic starter cultures, were obtained with the vitamin A spectra [16]. The quite standard deviation of these two parameters (2.56 and 2.84 for fat and DM, respectively) observed in the present study was also reported in the research of Karoui et al. [16] on soft cheese samples (2.19 and 2.27 for fat and DM, respectively).

Regarding the prediction of the $\mathrm{pH}$ value, the results obtained in the present study were less successful than those obtained by Karoui et al. [16] on 15 different soft cheeses. Indeed, the authors pointed out that the determination of the $\mathrm{pH}$ value by fluorescence techniques could be considered as approximate, while in the present study an unsuccessful result was obtained. One explanation could arise from the fact that a small range in the variation of the $\mathrm{pH}$ value was observed in the present study (standard deviation of 0.21 against 0.39 in the work of Karoui et al. [16]).

Concerning the prediction of TP, similar results to those observed with the investigation of Karoui et al. [16] was found, while the poorest results were obtained in the present study for SP compared with those observed by Karoui et al. [16] on 15 different soft cheeses. Again, this could 


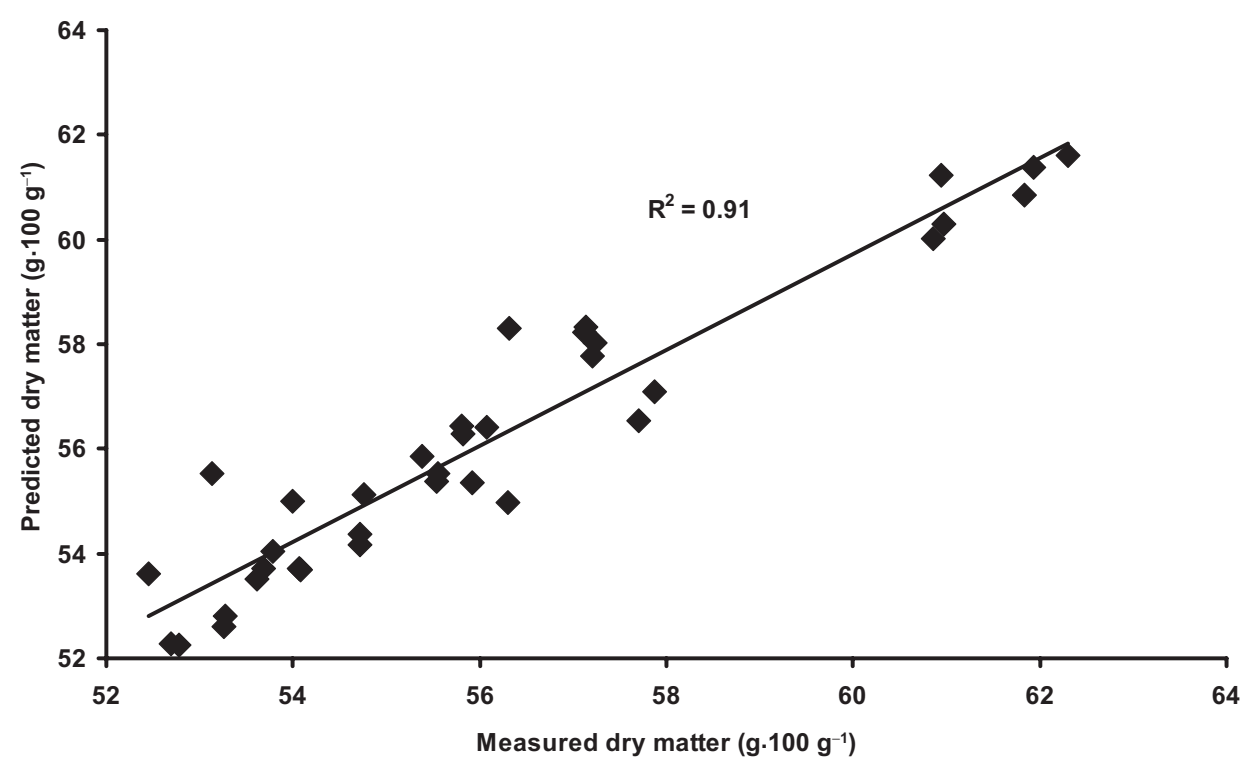

Figure 6. Partial least squares (PLS) prediction models: actual versus predicted value plots for cross-validation prediction of a training set of emission spectra scanned with excitation set at $380 \mathrm{~nm}$ using a portable spectrofluorometer for dry matter.

be explained by the low variation in the values of SP in the investigated cheeses. Thus, a high number of cheese samples presenting large variation in SP should be investigated in light of these findings.

\subsubsection{Prediction of chemical parameters with the portable spectrofluorometer}

The best results for fat, DM and TP were obtained with the excitation wavelength set at $380 \mathrm{~nm}$, while similar results were obtained for SP with the excitation wavelength set at $320 \mathrm{~nm}$ and $380 \mathrm{~nm}$, and quite similar results were obtained for $\mathrm{pH}$ values by using the excitation wavelength set at $280 \mathrm{~nm}$ and $320 \mathrm{~nm}$.

Based on the calibration data set, measurement of all the investigated chemical parameters with excitation at $380 \mathrm{~nm}$ were obtained after applying mean normalization to the fluorescence spectra data sets. Prediction of DM (Fig. 6) could be considered as excellent, while measurements of fat and TP could be considered as good by using the same excitation wavelength set at $380 \mathrm{~nm}$ (Tab. II). The determination of $\mathrm{SP}$ and $\mathrm{pH}$ with the excitation wavelength set at $380 \mathrm{~nm}\left(\mathrm{R}^{2}=0.65\right.$; $\mathrm{RPD}=1.66 ; \mathrm{RER}=5.09)$ and $280 \mathrm{~nm}$ $\left(\mathrm{R}^{2}=0.74 ; \mathrm{RPD}=1.98 ; \mathrm{RER}=5.44\right)$, respectively, could be considered as approximate. From the obtained results it can be concluded that the portable spectrofluorometer could be used successfully for measuring DM, fat and TP for the investigated cheeses. One of the main conclusions of this study was that the portable spectrofluorometer gave similar/better results than the laboratory spectrofluorometer. This could be a benefit for on-line measurement of such chemical parameters at the industrial level using the portable spectrofluorometer. It could also be an alternative method to the reference ones used to determine fat and TP, taking into account that the Kjeldahl and Gerber methods used 
for determining these parameters, respectively, in such cheeses are very expensive and need a long time.

In order to have an interpretation at the molecular level for the prediction of some chemical parameters, the regression coefficients of the PLS models were studied. Since the best results were obtained with the portable spectrofluorometer, only regression coefficients obtained with this apparatus were studied by using the excitation wavelength set at $380 \mathrm{~nm}$, except for the $\mathrm{pH}$ parameter where an excitation wavelength of $320 \mathrm{~nm}$ was considered. The regression coefficients of fat, DM, TP, SP and $\mathrm{pH}$ are shown in Figures $7 \mathrm{a}, 7 \mathrm{~b}, 7 \mathrm{c}, 7 \mathrm{~d}$ and $7 \mathrm{e}$, respectively.

The regression coefficient of fat indicates that $410-550 \mathrm{~nm}$ was the most important spectral region (Fig. 7a). The 560$705 \mathrm{~nm}$ spectral region also showed some modifications but less marked than the former one. Three peaks located at 419, 461 and $533 \mathrm{~nm}$ were correlated positively, while two other peaks located at 432 and $523 \mathrm{~nm}$ were negatively correlated with the fat. The peak located at $523 \mathrm{~nm}$ was attributed to riboflavin as reported by Wold et al. [27].

Regarding the regression coefficient of DM (Fig. 7b), two spectral regions located between $410-470 \mathrm{~nm}$ and $580-652 \mathrm{~nm}$ were interesting due to some correlation. Using only these two spectral regions, similar results to the model developed with the entire wavelength range (data not shown) was found. The regression coefficient of TP showed a strong positive peak located at $614 \mathrm{~nm}$ (Fig. 7c), while that of SP showed two strong negative peaks located at 470 and $624 \mathrm{~nm}$ and a positive peak located at $485 \mathrm{~nm}$ (Fig. 7d).

The regression coefficient of $\mathrm{pH}$ indicates a strong negative peak around $410 \mathrm{~nm}$, which could be due to vitamin A compound. This negative correlation indicates that a decrease in the maximum emission intensity around $410 \mathrm{~nm}$ occurred when the $\mathrm{pH}$ increased (Fig. 7e). This could be explained by the sensitive characteristic of vitamin A. Indeed, as vitamin A is present in the core and the membrane of fat globules, the modifications of $\mathrm{pH}$ could modify the ionization state as well as the hydration of some components such as proteins and phospholipids. These changes could induce some modifications in the environment of the fat globules and, as a consequence, in the membrane, that would affect the shape of vitamin A spectra [18].

\section{CONCLUSION}

This preliminary work demonstrated that it was possible to determine with excellent and good predictions DM and fat contents, respectively, of the investigated semi-hard cheeses by using portable spectrofluorometer, with the excitation wavelength set at $380 \mathrm{~nm}$. Using the laboratory spectrofluorometer with the excitation wavelength set at $320 \mathrm{~nm} / 380 \mathrm{~nm}$, the determination of DM and TP could be considered as approximate. Similar results were obtained with the portable spectrofluorometer with the excitation wavelength sets at $380 \mathrm{~nm}$ and $280 \mathrm{~nm}$ for the prediction of $\mathrm{SP}$ and $\mathrm{pH}$, respectively.

The portable spectrofluorometer, comprising a light-emitting diode (LED) for excitation, a spectrometer, a fiber optic and an integrated PC with a touch-screen for recording and evaluating data sets, demonstrated its accuracy and effectiveness in predicting DM and fat of 12 French semihard cheeses belonging to four brands by using partial least squares (PLS) regression. Simple to use, this portable spectrofluorometer provides a fast and accurate analysis in $1 \mathrm{~s}$, while $2 \mathrm{~min}$ is needed to acquire the same spectrum using the standard laboratory-based spectrofluorometer. Although we are still limited to testing the portable spectrofluorometer in dairy plants, which will be realized in the next five months, the results illustrated in the present 


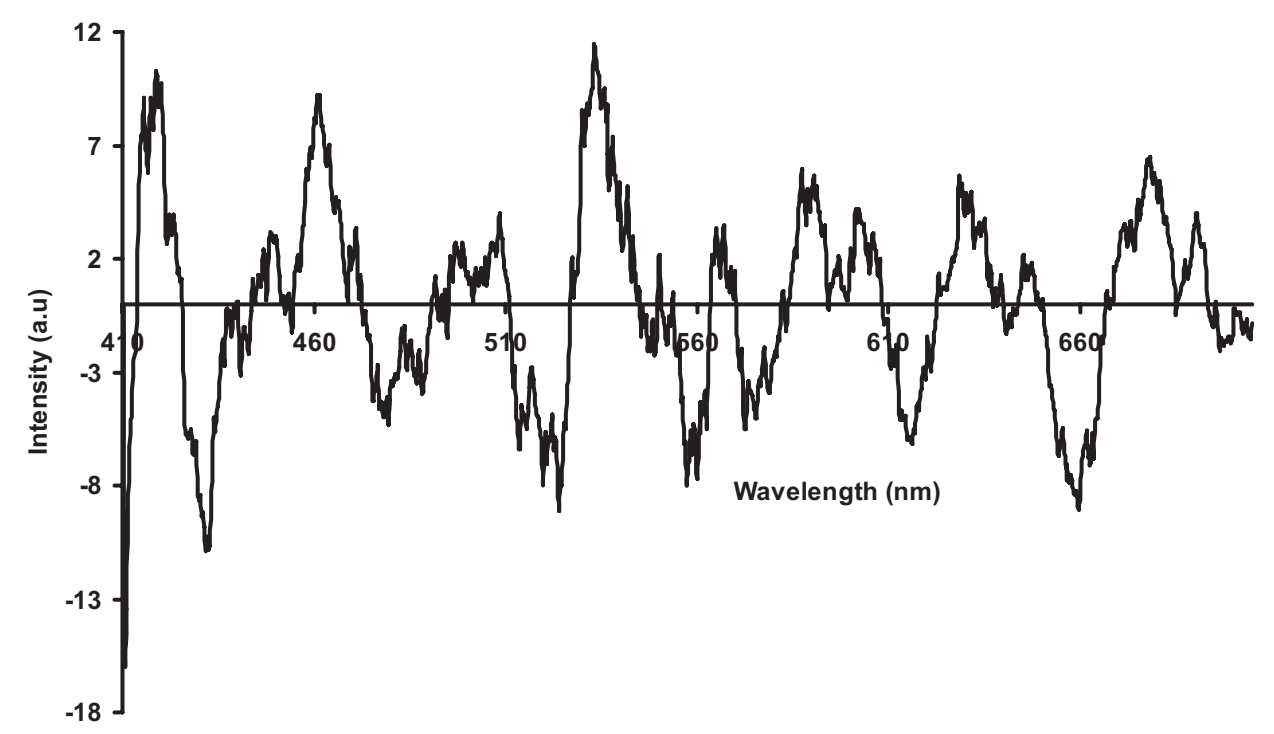

(a)

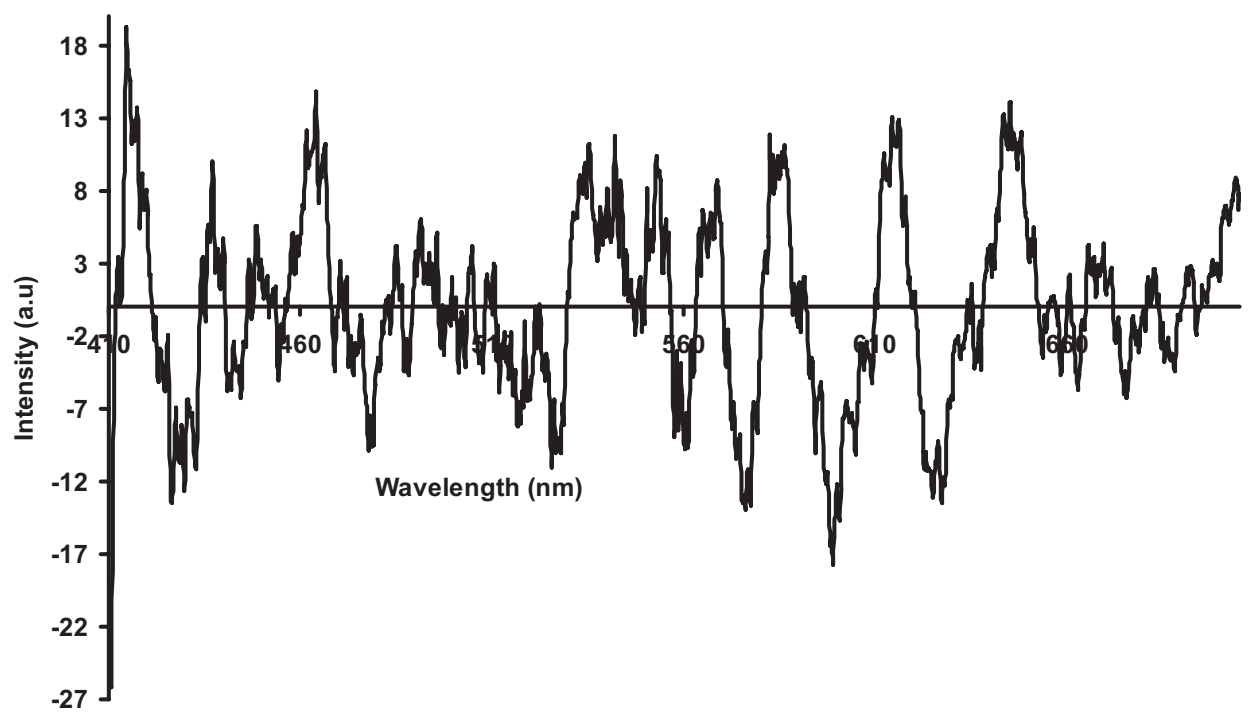

(b)

Figure 7. Regression coefficient distribution over the spectra scanned on Saint-Nectaire cheeses with excitation set at $380 \mathrm{~nm}$ using a portable spectrofluorometer for fat (a), dry matter (b), total protein (c) and soluble protein (d), and $320 \mathrm{~nm}$ for $\mathrm{pH}(\mathrm{e})$. 


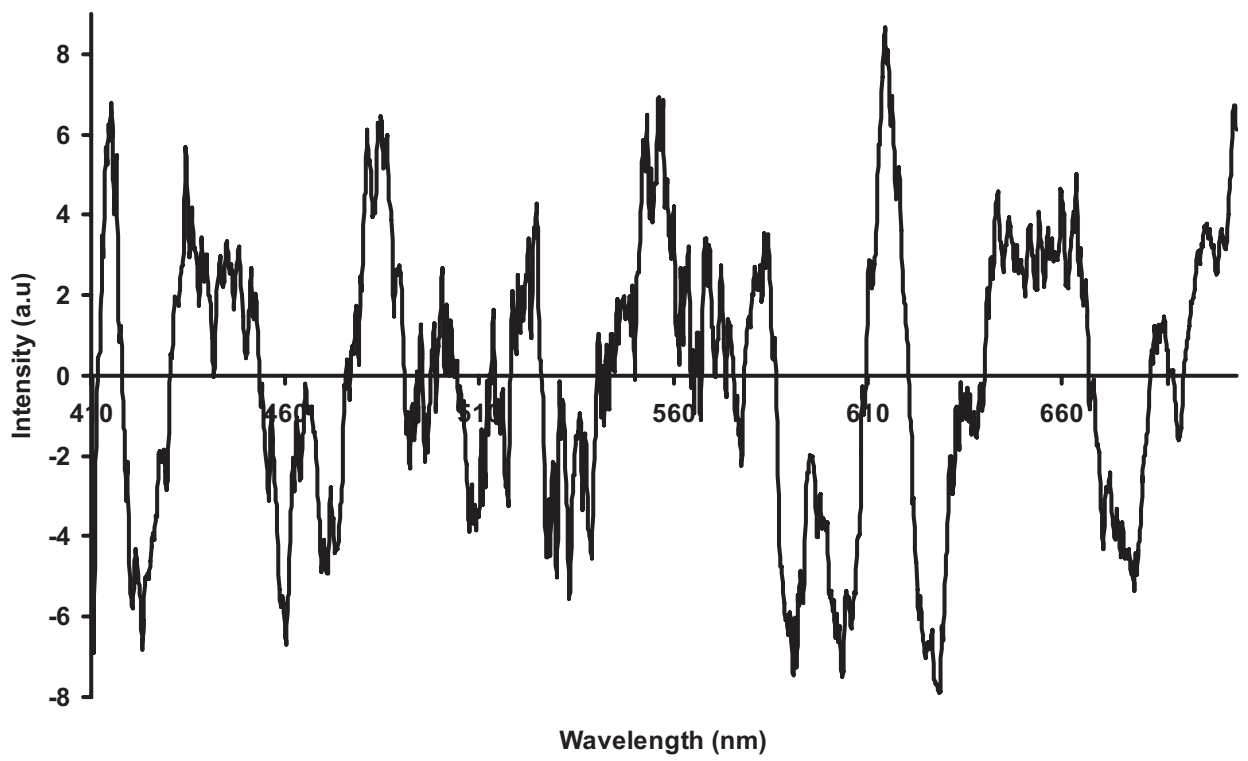

(c)

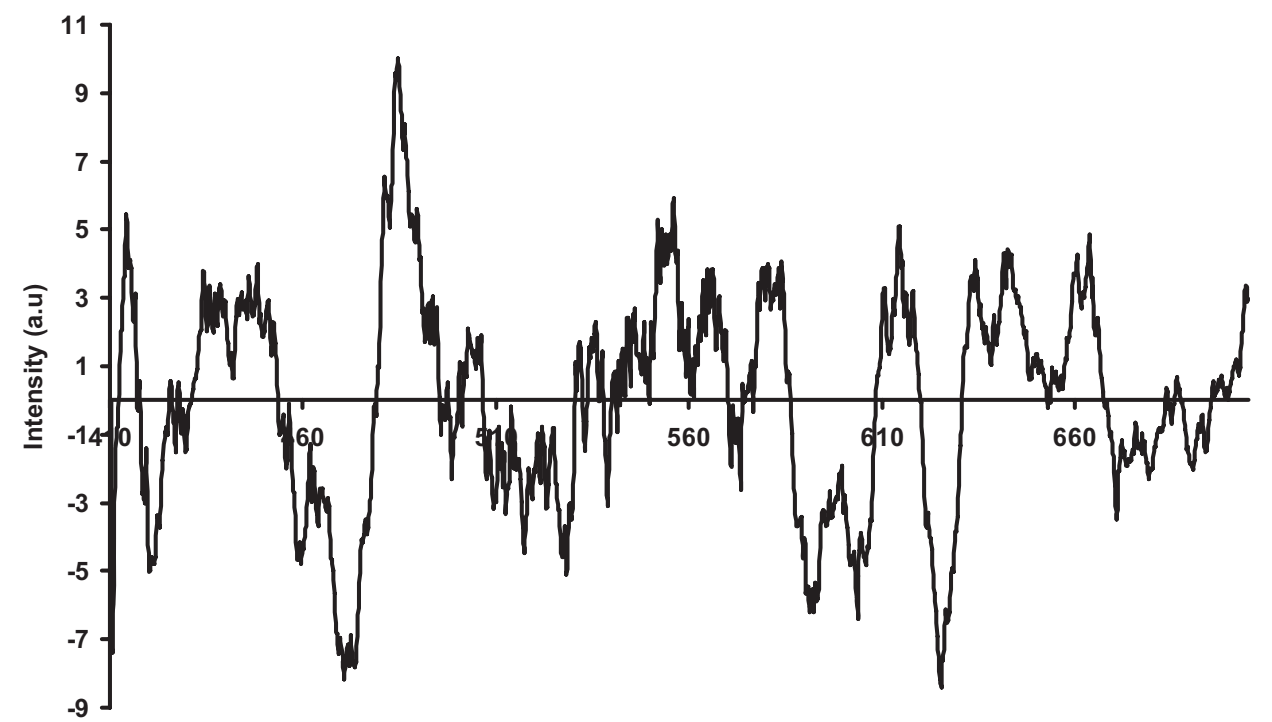

Wavelength $(\mathrm{nm})$

(d)

Figure 7. Continued. 


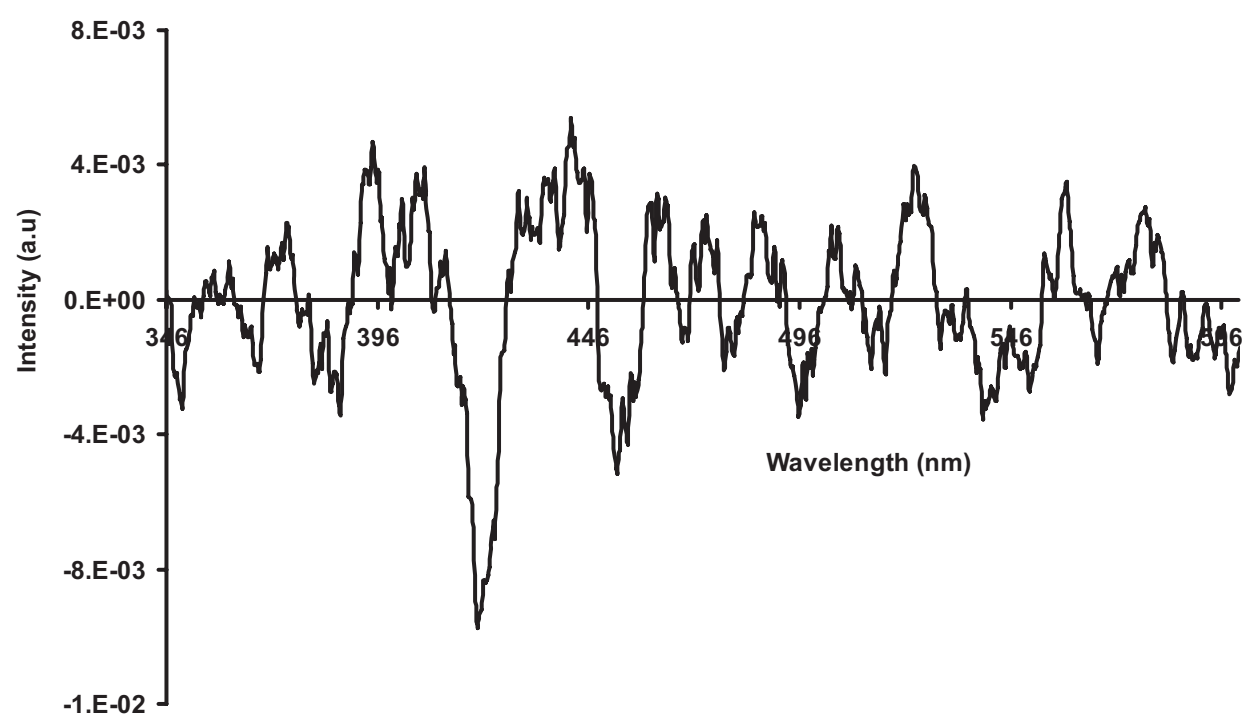

(e)

Figure 7. Continued.

study, among others, appear to be very encouraging in considering this prototype as the starting point for a new low-cost technology and a rapid tool for the evaluation of dairy products as an on-line technique.

The simplicity of the new portable spectrofluorometer offers rich opportunities for efficient characterization of cheese products among others at a relatively low cost. In addition, the portable spectrofluorometer has the potential of dramatically reducing the analytical time when looking at physico-chemical measurements.

Acknowledgements: We gratefully acknowledge the following French institutions for their financial support: Auvergne Valorisation, Busi, Clermont Communauté, Conseil Régional Auvergne, ENITA Clermont, Ministère de l'Enseignement Supérieur et de la Recherche and Oséo.

\section{REFERENCES}

[1] Agabriel C., Coulon J.B., Journal C., Sibra C., Albouy H., Effect of milk composi- tion and herd management conditions on the characteristic of farmhouse Saint-Nectaire cheese, Lait 79 (1999) 291-302.

[2] Bouton Y., Guyot P., Dasen A., Grappin R., Activité protéolytique de souches de lactobacilles thermophiles isolées de levains et de Comté. II - Applications en sites industriels, Lait 74 (1994) 33-46.

[3] Christensen J., Miquel Becker E., Frederiksen C.S., Fluorescence spectroscopy and PARAFAC in the analysis of yogurt, Chemometr. Intell. Lab. 75 (2005) 201-208.

[4] Dufour E., Mazerolles G., Devaux M.F., Duboz G., Duployer M.H., Mouhous Riou N., Phase transition of triglycerides during semi-hard cheese ripening, Int. Dairy J. 10 (2000) 81-93.

[5] Dufour E., Riaublanc A., Potentiality of spectroscopic methods for the characterisation of dairy products. I. Front-face fluorescence study of raw, heated and homogenised milks, Lait 77 (1997) 657-670.

[6] Hansen E., Skibsted L.H., Light-induced oxidative changes in a model dairy spread. Wavelength dependence of quantum yields, J. Agric. Food Chem. 48 (2000) 3090-3094.

[7] Herbert S., Riaublanc A., Bouchet B., Gallant D.J., Dufour E., Fluorescence spectroscopy investigations of acid-and 
rennet-induced milk coagulation of milk, J. Dairy Sci. 82 (1999) 2056-2062.

[8] Karoui R., Bosset J.O., Mazerolles G., Kulmyrzaev A., Dufour E., Monitoring the geographic origin of both experimental French Jura hard cheeses and Swiss Gruyère and l'Etivaz PDO cheeses using mid-infrared and fluorescence spectroscopies, Int. Dairy J. 15 (2005) 275-286.

[9] Karoui R., De Baerdemaeker J., Dufour E., A comparison and joint use of mid infrared and fluorescence spectroscopic methods for differentiating between manufacturing process and sampling zones of ripened soft cheeses, Eur. Food Res. Technol. 226 (2008) 861870.

[10] Karoui R., De Baerdemaeker J., Dufour E., Utilisation of front face fluorescence spectroscopy as a tool for the prediction of some chemical parameters and the melting point of semi-hard and hard cheeses: A preliminary study, Eur. Food Res. Technol. 226 (2008) 1119-1126.

[11] Karoui R., Dufour E., Dynamic testing rheology and fluorescence spectroscopy investigations of surface to centre differences in ripened soft cheeses, Int. Dairy J. 13 (2003) 973-985.

[12] Karoui R., Dufour E., Pillonel L., Picque D., Cattenoz T., Bosset J.O., Determining the geographic origin of Emmental cheeses produced during winter and summer using a technique based on the concatenation of MIR and fluorescence spectroscopic data, Eur. Food Res. Technol. 219 (2004) 184-189.

[13] Karoui R., Dufour E., Pillonel L., Picque D., Cattenoz T., Bosset J.O., Fluorescence and infrared spectroscopies: a tool for the determination of the geographic origin of Emmental cheeses manufactured during summer, Lait 84 (2004) 359-374.

[14] Karoui R., Dufour E., Pillonel L., Schaller E., Picque D., Cattenoz T., Bosset J.O., The potential of determination of the geographic origin of Emmental cheeses by combining infrared and fluorescence spectroscopies, Int. Dairy J. 15 (2005) 287-298.

[15] Karoui R., Laguet A., Dufour E., Fluorescence spectroscopy: a tool for the investigation of cheese melting - correlation with rheological characteristics, Lait 83 (2003) 251-264.

[16] Karoui R., Martin B., Dufour E., Potentiality of front-face fluorescence spectroscopy to determine the geographic origin of milks from Haute-Loire department (France), Lait 85 (2005) 223-236.

[17] Karoui R., Mouazen A.M., Dufour E., Pillonel L., Picque D., Bosset J.O.,
De Baerdemaeker J., Mid infrared spectrometry: a tool for the determination of chemical parameters in Emmental cheeses produced during winter, Lait 86 (2006) 83-97.

[18] Karoui R., Mouazen A.M., Dufour E., Schoonheydt R., De Baerdemaeker J., Utilisation of front-face fluorescence spectroscopy for the determination of some chemical parameters in soft cheeses, Lait 86 (2006) 155-169.

[19] Kikugawa K., Beppu M., Involvement of lipid oxidation products in the formation of fluorescent and cross-linked proteins, Chem. Physic Lipids 44 (1987) 277-296.

[20] Kulmyrzaev A., Dufour E., Determination of lactulose and furosine in milk using front-face fluorescence spectroscopy, Lait 82 (2002) 725-735.

[21] Miquel Becker E., Christensen J., Frederiksen C.S., Haugaard V.K., Front face fluorescence spectroscopy and chemometrics in analysis of yogurt: rapid analysis of riboflavin, J. Dairy Sci. 86 (2003) 2508-2515.

[22] Mouazen A.M., De Baerdemaeker J., Ramon H., Towards development of on-line soil moisture content sensor using a fibre-type NIR spectrophotometer, Soil. Till. Res. 80 (2005) 171-183.

[23] Purna G.S.K., Prow L.A., Metzger L.E., Utilization of front-face fluorescence spectroscopy for analysis of process cheese functionaliaty, J. Dairy Sci. 88 (2005) 470-477.

[24] Rouissi H., Dridi S., Kammoun M., De Baerdemaeker J., Karoui R., Front face fluorescence spectroscopy: a rapid tool for determining the effect of replacing soybean meal with scotch bean in the ration on the quality of Sicilo-Sarde ewe's milk during lactation period, Eur. Food Res. Technol. 226 (2008) 1021-1030.

[25] Verdier-Metz I., Coulon J.B., Pradel P., Viallon C., Albouy H., Berdagué J.L., Effect of the botanical composition of hay and casein genetic variants on the chemical and sensory characteristics of ripened SaintNectaire type cheeses, Lait 80 (2000) 361370.

[26] Williams P.C., Near-Infrared Technology Getting the Best out of Light, PDK Grain, Nanaimo, Canada, 2003.

[27] Wold J.P., Veberg A., Nilsen A., Iani V., Juzenas P., Moan J., The role of naturally occurring chlorophyll and porphyrins in lightinduced oxidation of dairy products. A study based on fluorescence spectroscopy and sensory analysis, Int. Dairy J. 15 (2005) 343353. 